\title{
Mixed cropping experiments with maize and groundnuts
}

\author{
H. J. W. Mutsaers ${ }^{1}$ \\ ENSA, University of Yaoundé, BP 138, Yaoundé, Cameroon
}

Accepted: 31 March 1978

Key words: mixed cropping, maize, groundnuts

\section{Summary}

Experiments were carried out during three seasons in the Yaoundé area, Cameroon, in order to evaluate maize-groundnut mixtures, as compared with pure stands. Both crops had similar growth duration. Total grain yields of both crops combined were lower for mixtures than for pure maize, but mixtures were found to be advantageous over pure stands in terms of relative yield total (RYT): in the September - December season of 1975 an average of $6 \%$ more area would have been needed in pure stands to attain the same yield of each species as in the mixtures. In the March - July season of 1976 this was $16 \%$.

The results are discussed in terms of limiting factors. Results of a third experiment suggest that the mixtures reduce the risk of supra-optimal population density as compared with pure maize under severely limiting $\mathrm{N}$ availability.

\section{Introduction}

In the humid and sub-humid regions of South Cameroon food crops are grown according to a shifting cultivation system. After each fallow a mixture of crops is planted including 'short-cycle crops' like groundnuts and maize and 'long-cycle crops' like tuber crops and plantains. Generally all crops are planted at the same time. Groundnuts are the principal short cycle crop, maize being interplanted at a fairly low density.

In the densely populated areas of Western Cameroon the farmer practises virtually a continuous cropping system. Here maize is a major crop and mixed cultivation of maize and groundnuts is also practised.

The agricultural extension services have for some time tried to discourage mixed cropping in favour of growing all species as single species crops. This would only be sound if more area of mixed crops were needed than of single species crops in order to attain the same yield of each species (the farmer wants to grow both crops in each season).

1 Present address: Department of Tropical Crops, Agricultural University, Wageningen, the Netherlands. 


\section{MIXED CROPPING EXPERIMENTS WITH MAIZE AND GROUNDNUTS}

Examples of proven superiority of intercropping (long-cycle crops intercropped with short-cycle crops) over pure stands however are fairly numerous (e.g. Andrews, 1972; Willey \& Osiru 1972; Osiru \& Willey, 1972; Norman, 1974; Fisher et al., 1976). Fisher, however, found that superiority of long-cycle maize, intercropped with short-cycle beans (Phaseolus vulgaris) over the pure crops was only found under conditions of non-limiting rainfall (Fisher, 1977). In some cases mixtures of crops of comparable growth cycle have also been found to be advantageous, especially mixtures of leguminous and non-leguminous plants (e.g. IRRI, 1974; Syarifuddin et al., 1974; Beets, 1977).

The present experiments were set up in order to evalute mixed cropping of maize and groundnuts, both of similar growth cycle, for the Yaoundé area, South Cameroon. Only productional aspects were studied.

\section{Material and methods}

The experiments were carried out at the experimental farm of the University of Yaoundé College of Agriculture and covered three growing seasons: September December 1975 and March - July 1976 (Experiments 1 and 2) and September December 1976 (Experiment 3).

Some climatological data for the Yaoundé area are given in Table 1.

\section{Experiments 1 and 2}

The soil is a fairly fertile deep alluvial soil of clay-loam texture. The experimental treatments were as follows:

1. pure groundnuts

2. groundnuts full + maize $1 / 3$

3. groundnuts $2 / 3+$ maize $1 / 3$

4. groundnuts full + maize $2 / 3$

G $1 / 1$

G $1 / 1$

G $2 / 3$

M $1 / 3$

G $1 / 1$

M $1 / 3$

G $1 / 3$

M $2 / 3$

5. groundnuts $1 / 3+$ maize $2 / 3$

M $2 / 3$

6. pure maize

M $1 / 1$

The pure groundnuts and pure maize treatments were sown at $40 \mathrm{~cm} \times 10 \mathrm{~cm}$ and $80 \mathrm{~cm} \times 30 \mathrm{~cm}$, respectively (250000 and 41666 plants per ha). Treatments 2 and 4 had the full density of groundnuts, interplanted with rows of maize at $1 / 3$ and $2 / 3$ of the density of pure maize, respectively. In treatments 3 and 5 each plant of maize replaced 6 plants of groundnuts, in proportion with their density in pure stands. The field lay-out is shown in Fig. 1.

Thus the experiment included two partially overlapping series of treatments: a

Table 1. Rainfall and mean monthly temperature for the experimental periods.

\begin{tabular}{lrrrrrrrr}
\hline & Sep. & \multicolumn{1}{c}{ Oct. } & Nov. & Dec. & Mar. & Apr. & May & June \\
& 1975 & 1975 & 1975 & 1975 & 1976 & 1976 & 1976 & 1976 \\
Rainfall (mm) & & & & & & & & \\
Mean temp. $\left({ }^{\circ} \mathrm{C}\right)$ & 22.4 & 185.2 & 182.0 & 1.6 & 124.1 & 168.3 & 164.2 & 159.6 \\
\hline
\end{tabular}



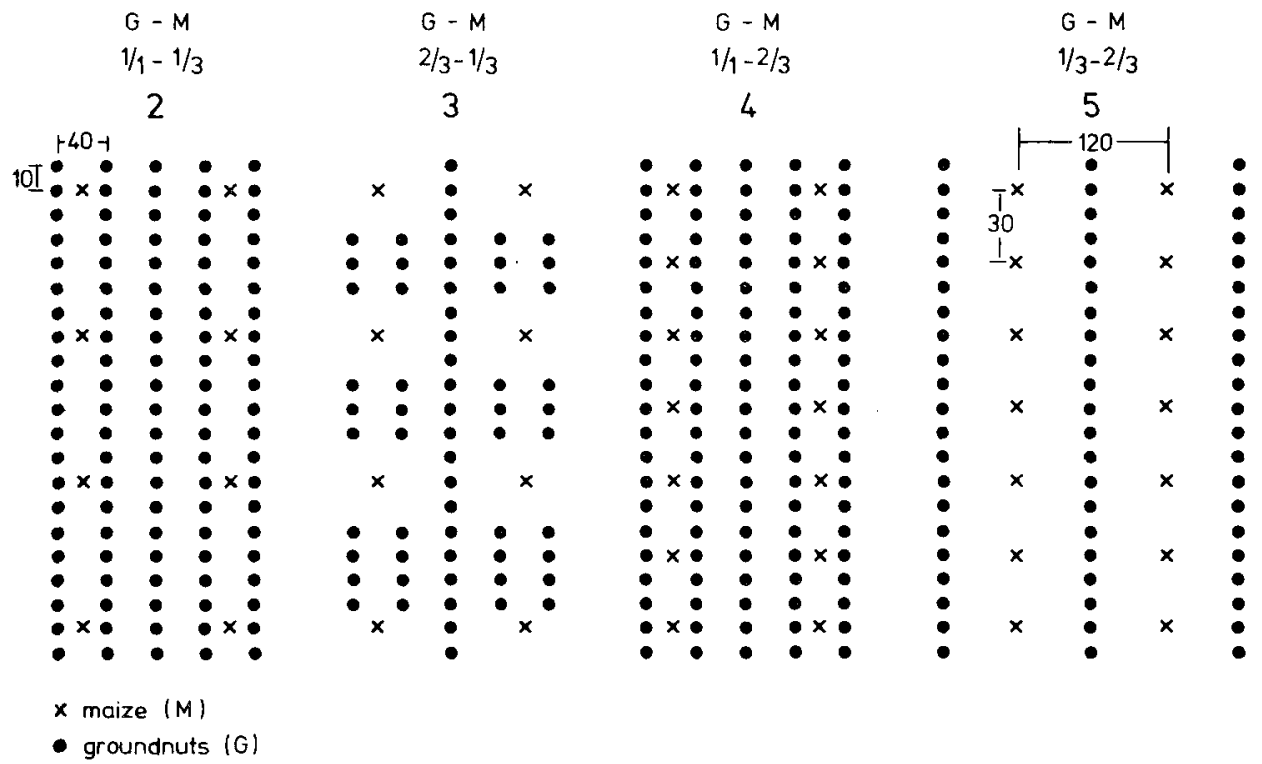

Fig. 1. Field lay-out of the experimental treatments 2 to 5 (see text) of Exp. 1 and 2.

'replacement series' (treatments 1, 3, 5, 6) and an 'addition series' (treatments 1, 2, $4,6)$. Each treatment plot was subdivided into two, one subplot receiving fertilizer $\left(F_{1}\right)$, the other not $\left(F_{0}\right)$. The $F_{1}$ subplots were all given a pre-sowing dose of $60 \mathrm{~kg}$ $\mathrm{P}_{2} \mathrm{O}_{5}$ per ha, as double calcium phosphate in 1975 and as mono-superphosphate in 1976. Each maize plant in the $F_{1}$ plots was given individually $6 \mathrm{~g}$ of urea, thus avoiding an extra nitrogen supply to the groundnuts in the mixtures.

The trials were carried out in 6 replications, 3 of them having an approximately north-south row orientation, the others east-west.

Thus the experiment was a split-plot design with the orientations as main units and with two subdivisions, one for treatments, one for fertilizers.

Each plot had a gross surface of $6.0 \mathrm{~m} \times 7.2 \mathrm{~m}$ and a net surface (after discarding surrounds) of $3.6 \mathrm{~m} \times 4.8 \mathrm{~m}$. For maize a local strain of the 'Cuban Yellow' cultivar was used, for groundnuts a bunch type selection of the College of Agriculture, called ' $68-45$ '.

The groundnuts were regularly sprayed with Sumifene against Aphis laburni Kalt., the vector of rosette virus, and with Benlate against leaf spot. Maize was sprayed once with Lindane against stemborers. At harvest the following measurements were carried out:

for maize $\quad$ - weight of straw

- number of ears per plant

- weight of grains

- 1000-grain weight (only in 1976)

- dry weight \% of all plant parts. 
Table 2. Dates of sowing and harvest of maize and groundnuts.

\begin{tabular}{|c|c|c|c|c|}
\hline \multirow[t]{2}{*}{ Season } & \multicolumn{2}{|l|}{ Maize } & \multicolumn{2}{|l|}{ Groundnuts } \\
\hline & sowing & harvest & sowing & harvest \\
\hline Sep. - Dec. $1975^{1}$ & $26 / 8-28 / 8$ & $29 / 12-31 / 12$ & $26 / 8-28 / 8$ & $17 / 12-24 / 12$ \\
\hline Mar. - July 1976 & $18 / 3-20 / 3$ & $5 / 7-7 / 7$ & $18 / 3-20 / 3$ & $17 / 6-22 / 6$ \\
\hline Sep. - Dec. 1976 & $10 / 9-11 / 9$ & $30 / 12-31 / 12$ & $10 / 9-11 / 9$ & $9 / 12-11 / 12$ \\
\hline
\end{tabular}

1 Crops did not germinate until 2 weeks after sowing.

for groundnuts - weight of tops

- weight of pods

- weight of seeds

- 1000-seed weight (only in 1976)

- dry weight $\%$ of all plant parts.

\section{Experiment 3}

This experiment was carried out as a verification of the assumption derived from Experiments 1 and 2, that the performance of crop mixtures might be influenced by fertility.

The soil is an oxisol, normally used for semi-permanent cropping by the farm labourers, and of poor fertility. The experiment had to be limited to four treatments due to lack of space. The treatments were an addition series as follows:

1. pure groundnuts

2. groundnuts full + maize $1 / 3$

3. groundnuts full + maize $2 / 3$

4. pure maize.

Each plot was split into an $\mathrm{F}_{\mathbf{0}}$ and an $\mathrm{F}_{1}$ subplot. $\mathrm{N}$ and $\mathrm{P}$ fertilizer doses in the $F_{1}$ plots were identical to Experiment 1, 1976.

The $F_{1}$ plots also received a dose of $\mathrm{K}$ equivalent to $84 \mathrm{~kg}$ of $\mathrm{K} 60$ per ha. The experiment was set up in five replications but one replication was discarded because of extreme variability caused by one practically sterile corner in the field. Gross surface of the plots was $4.60 \mathrm{~m} \times 4.80 \mathrm{~m}$, net surface $2.80 \mathrm{~m} \times 3.60 \mathrm{~m}$. Phytosanitary treatments were identical to those of Experiments 1 and 2. Planting and harvest dates are given in Table 2 .

\section{Results and discussion}

\section{Experiments 1 and 2}

Average yields of field dry seeds of maize and groundnuts for both seasons are presented in Fig. 2. Analysis of variance was executed separately for maize and groundnuts yields.

The results for maize are as follows:

- The overall treatment effect as well as the fertilizer effect were significant at the $99 \%$ probability level for both seasons. 


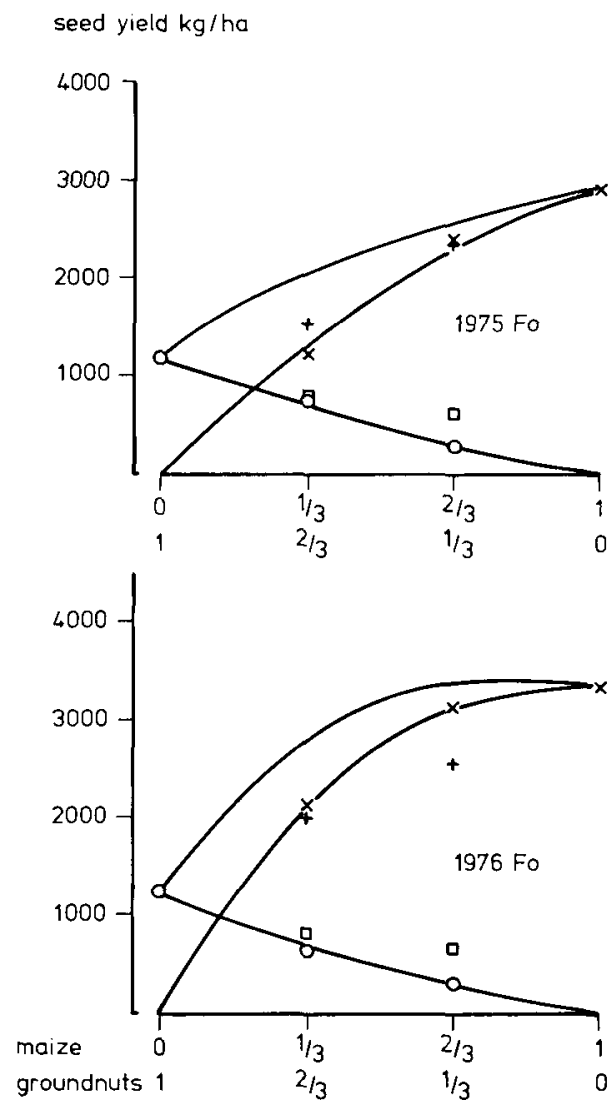

seed yield $\mathrm{kg} / \mathrm{ha}$
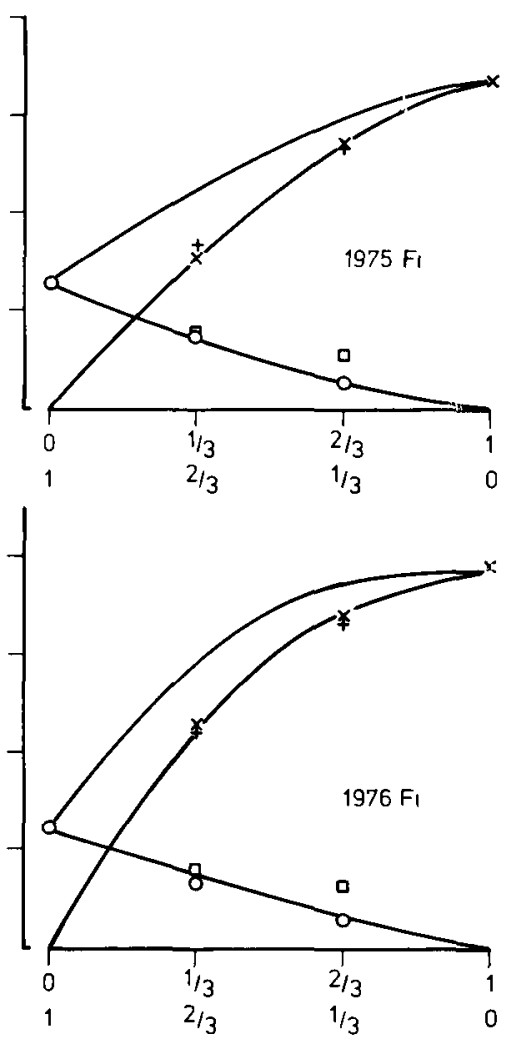

Fig. 2. Yield of maize and groundnuts in pure stands and mixtures, Exp. 1 and 2. Replacement series (drawn curves): $\times$ maize, treatments $3,5,6$; $\bigcirc$ groundnuts, treatments $1,3,5$. Addition series, full groundnuts density: + maize, treatments $2,4,6 ; \square$ groundnuts, treatments $1,2,4$. $F_{0}:$ unfertilized; $F_{1}$ : fertilized (see text).

- In both seasons there was no significant overall difference between treatments 2 and 4 on one hand and 3 and 5 on the other. This means that maize yield did not decrease significantly with an increase in groundnut density from $2 / 3$ or $1 / 3$ (treatments 3 and 5) to 'full density' (treatments 2 and 4) except perhaps for treatments 4 and 5, 1976, $F_{0}$ (see Fig. 2).

- No significant interaction was found between treatments and orientation in either season.

- The interaction between treatments and fertilizer was significant in the 1976 trial, but not so in the 1975 trial.

The results for groundnuts were as follows:

- The overall treatment effect is significant at the $99 \%$ probability level in both seasons. 
- No significant overall fertilizer effect was found in either season.

- No significant interaction was found between treatments and orientation.

Tables 3 and 4 show the yield components of maize and groundnuts at different treatments. For calculation of grain/straw ratio the loss of leaves for maize and groundnuts was visually estimated at $15 \%$ and $30 \%$ respectively, for all treatments.

For maize there is a decrease of number of cobs per plant with increasing density in both seasons. Both number of cobs per plant and weight of grains per cob (number of grains per cob) were higher for the fertilized plots.

Groundnuts reacted to increasing density mainly through a reduced number of pods per plant. The fairly stable grain/straw ratio shows that this was due to a reduced general development of the plants. Only in treatment 5, 1975, was the ratio appreciably lower than in the others. In 1976, the ratio was appreciably lower than in 1975 at practically equal seed yields. At about half-cycle the crop was seriously affected by leaf spot and the regular fungicide applications were only partially successful. Renewed vegetative growth resulted, which could not be transformed into grain yields.

\section{Mixtures versus pure stands}

As expected, maize is the stronger competitor in maize-groundnut mixtures.

Table 3a. Yield components for maize, Sep. - Dec. 1975 trial (Exp. 1).

\begin{tabular}{|c|c|c|c|c|c|c|}
\hline \multirow[t]{2}{*}{ Treatments } & \multicolumn{2}{|c|}{$\begin{array}{l}\text { Number of cobs } \\
\text { per plant }\end{array}$} & \multicolumn{2}{|c|}{$\begin{array}{l}\text { Weight of grains } \\
\text { per cob (g) }\end{array}$} & \multicolumn{2}{|c|}{$\begin{array}{l}\text { Grain/straw ratic } \\
\text { (dry matter) })^{1}\end{array}$} \\
\hline & $F_{0}$ & $F_{1}$ & $\mathbf{F}_{0}$ & $\mathrm{~F}_{1}$ & $\mathrm{~F}_{0}$ & $F_{1}$ \\
\hline 2 & 1.26 & 1.40 & 100.7 & 97.5 & 0.51 & 0.44 \\
\hline 3 & 1.19 & 1.46 & 85.8 & 89.0 & 0.44 & 0.43 \\
\hline 4 & 1.22 & 1.20 & 81.8 & 94.5 & 0.52 & 0.56 \\
\hline 5 & 1.09 & 1.18 & 93.7 & 97.2 & 0.50 & 0.49 \\
\hline 6 & 0.93 & 1.03 & 88.4 & 92.7 & 0.48 & 0.46 \\
\hline
\end{tabular}

I Straw includes threshed cobs.

Table 3b. Yield components for groundnuts, Sep. - Dec. 1975 trial (Exp. 1).

\begin{tabular}{|c|c|c|c|c|c|c|}
\hline \multirow[t]{2}{*}{ Treatments } & \multicolumn{2}{|c|}{ Number of pods per plant } & \multicolumn{2}{|c|}{ Weight of seeds per pod (g) } & \multicolumn{2}{|c|}{ Grain/straw ratio ${ }^{2}$} \\
\hline & $\mathbf{F}_{0}$ & $\mathbf{F}_{1}$ & $\mathrm{~F}_{0}$ & $F_{1}$ & $\mathrm{~F}_{0}$ & $F_{1}$ \\
\hline 1 & 5.9 & 6.2 & 0.92 & 0.97 & 0.50 & 0.54 \\
\hline 2 & 4.2 & 3.9 & 0.88 & 0.94 & 0.50 & 0.56 \\
\hline 3 & 5.8 & 5.5 & 0.91 & 0.92 & 0.54 & 0.47 \\
\hline 4 & 2.9 & 2.9 & 1.01 & 0.91 & 0.50 & 0.48 \\
\hline 5 & 4.0 & 4.0 & 0.97 & 0.98 & 0.41 & 0.44 \\
\hline
\end{tabular}

2 Straw includes emptied pods. 
Table 4a. Yield components of maize, March - July 1976 trial (Exp. 2).

\begin{tabular}{|c|c|c|c|c|c|c|c|c|}
\hline \multirow[t]{2}{*}{$\begin{array}{l}\text { Treat- } \\
\text { ments }\end{array}$} & \multicolumn{2}{|c|}{$\begin{array}{l}\text { Number of cobs } \\
\text { per plant }\end{array}$} & \multicolumn{2}{|c|}{$\begin{array}{l}\text { Number of grains } \\
\text { per cob }\end{array}$} & \multicolumn{2}{|c|}{$\begin{array}{l}\text { 1000-grain } \\
\text { weight }(\mathrm{g})\end{array}$} & \multicolumn{2}{|c|}{$\begin{array}{l}\text { Grain/straw ratio } \\
\text { (dry matter) }^{1}\end{array}$} \\
\hline & $F_{0}$ & $F_{1}$ & $\mathrm{~F}_{0}$ & $F_{1}$ & $F_{0}$ & $F_{1}$ & $\mathrm{~F}_{0}$ & \\
\hline 2 & 1.49 & 1.58 & 399 & 422 & 253 & 256 & 0.47 & 0.50 \\
\hline 3 & 1.58 & 1.67 & 398 & 408 & 261 & 260 & 0.50 & 0.45 \\
\hline 4 & 1.06 & 1.22 & 366 & 416 & 251 & 255 & 0.42 & 0.46 \\
\hline 5 & 1.18 & 1.26 & 409 & 399 & 252 & 263 & 0.46 & 0.46 \\
\hline 6 & 1.01 & 1.03 & 363 & 383 & 234 & 253 & 0.43 & 0.43 \\
\hline
\end{tabular}

${ }^{1}$ See Table 3a.

Table 4b. Yield components of groundnuts, March - July 1976 trial (Exp. 2).

\begin{tabular}{lllllllll}
\hline $\begin{array}{l}\text { Treat- } \\
\text { ments }\end{array}$ & \multicolumn{2}{l}{$\begin{array}{l}\text { Number of pods } \\
\text { per plant }\end{array}$} & \multicolumn{2}{l}{$\begin{array}{l}\text { Number of grains } \\
\text { per pod }\end{array}$} & \multicolumn{2}{l}{$\begin{array}{l}\text { 1000-grain } \\
\text { weight }(\mathrm{g})\end{array}$} & \multicolumn{2}{l}{ Grain/straw ratio } \\
& $\mathrm{F}_{0}$ & $\mathrm{~F}_{1}$ & $\mathrm{~F}_{0}$ & $\mathrm{~F}_{1}$ & $\mathrm{~F}_{\mathbf{0}}$ & $\mathrm{F}_{1}$ & $\mathrm{~F}_{0}$ & $\mathrm{~F}_{\mathbf{1}}$ \\
& & & & & & & & \\
1 & 5.9 & 5.8 & 2.1 & 2.1 & 428 & 418 & 0.26 & 0.24 \\
2 & 3.8 & 3.8 & 2.2 & 2.1 & 420 & 412 & 0.25 & 0.24 \\
3 & 4.8 & 4.8 & 2.0 & 2.1 & 418 & 423 & 0.23 & 0.23 \\
4 & 3.2 & 3.0 & 2.1 & 2.2 & 418 & 422 & 0.24 & 0.21 \\
5 & 4.3 & 4.2 & 2.2 & 2.2 & 403 & 416 & 0.24 & 0.24 \\
\hline
\end{tabular}

${ }^{2}$ See Table 3b.

Groundnut yields were reduced progressively by higher densities of maize. Performance of the mixtures as compared with pure stands is generally judged in terms of relative yield total (RYT) (de Wit \& van den Bergh, 1965; Trenbath, 1976). This comparison is only valid for mixtures having the same population pressure as the pure stands, i.e. our replacement series. Yield of the components is expressed as yield relative to pure stand yield. For two species competing for the same limiting

Table 5. Average relative yield totals for maize-groundnuts mixtures.

\begin{tabular}{|c|c|c|c|c|c|}
\hline & \multirow{2}{*}{$\begin{array}{l}\text { Treat- } \\
\text { ments }\end{array}$} & \multicolumn{2}{|c|}{ Sep. - Dec. 1975} & \multicolumn{2}{|c|}{ Mar. - July 1976} \\
\hline & & $\overline{F_{0}}$ & $\mathrm{~F}_{1}$ & $\overline{F_{0}}$ & $F_{1}$ \\
\hline \multirow{4}{*}{$\begin{array}{l}\text { 'replacement } \\
\text { series' }\end{array}$} & 3 & 1.10 & 1.03 & 1.25 & 1.13 \\
\hline & 5 & 1.08 & 1.03 & 1.17 & 1.09 \\
\hline & average & 1.09 & 1.03 & $1.21 *$ & $1.11 * *$ \\
\hline & $\mathrm{SE}_{\mathrm{av}}$ & 0.061 & 0.037 & 0.077 & 0.033 \\
\hline
\end{tabular}

* Significantly different from 1.0 at the $95 \%$ probability level.

** Significantly different from 1.0 at the $99 \%$ probability level. 
growth factors, the RYT, i.e. the sum of the relative yields of the components, will be unity (de Wit \& van den Bergh, 1965). Table 5 shows that RYT appears to be larger than unity in these experiments. Results of a statistical analysis of the RYTs, calculated separately for each replication (Table 5), shows that they were significantly larger than unity in 1976 but not so in 1975 . One very low RYT value for a treatment $5, F_{0}$ plot in $1975(0.69)$, could however be traced back to a larger than average loss of maize plants. If this value is excluded, the average RYT for treatments 3 and 5 would be 1.13 and its SE 0.054 , and RYT would be significantly larger than unity $(\mathrm{P}<0.05)$. It appears that maize and groundnuts did not compete for the same limiting factor.

Under humid or subhumid tropical conditions water is not normally a limiting factor. The most generally limiting factor in smallholders' crops is nitrogen. In a mixture of maize and groundnuts, however, the latter crop will not compete for the limited supply of nitrogen to any great extent. Each maize plant will therefore have a larger volume of soil available for its $\mathrm{N}$ supply than in pure stands. This will lead to a RYT larger than unity. This effect is expected to be less in the case of fertile soil or of the use of fertilizer. In the present trials there was a slight, though not statistically significant tendency for mixtures to show a greater advantage over pure stands in unfertilized than in fertilized plots. If this is real, one would expect to find a more clear-cut difference between fertilized and unfertilized plots on poorer soils.

One would also expect maize-groundnut mixtures to tolerate a higer population pressure than pure maize stands under conditions of limiting nitrogen. Experiment 3 was set up as a preliminary experiment to study these aspects.

\section{Experiment 3}

The experiment was laid out on a small and very variable farmer's field of unknown

Table 6. Yields of maize and groundnuts, cobs per plant of maize and LER values, Sep. - Dec. 1976 trial (Exp. 3), four replications.

\begin{tabular}{|c|c|c|c|c|}
\hline Parameter & Treatment 1 & Treatment 2 & Treatment 3 & Treatment 4 \\
\hline Code & G $1 / 1$ & $\mathrm{G} 1 / 1 \mathrm{M} 1 / 3$ & $\mathrm{G} 1 / 1 \mathrm{M} 2 / 3$ & M $1 / 1$ \\
\hline \multicolumn{5}{|l|}{ Yields (kg seeds per ha) } \\
\hline$F_{0}$, maize & 一 & 769.5 & 861.9 & 1380.6 \\
\hline$F_{0}$, groundnuts & 613.9 & 417.0 & 442.7 & - \\
\hline$F_{1}$, maize & - & 992.0 & 1518.7 & 2401.0 \\
\hline$F_{1}$, groundnuts & 583.4 & 442.1 & 503.4 & - \\
\hline \multicolumn{5}{|l|}{ Cobs of maize per plant } \\
\hline $\mathbf{F}_{0}$ & 一 & 0.91 & 0.75 & 0.69 \\
\hline$F_{1}$ & - & 0.99 & 0.92 & 0.94 \\
\hline \multicolumn{5}{|l|}{$\begin{array}{l}\text { Land equivalent ratios } \\
\text { as calculated from }\end{array}$} \\
\hline each replication, $\mathbf{F}_{\mathbf{0}}$ & 一 & 1.53 & 1.70 & - \\
\hline each replication, $F_{1}$ & 一 & 1.19 & 1.46 & - \\
\hline average yields, $F_{0}$ & 一 & 1.24 & 1.34 & - \\
\hline average yields, $F_{1}$ & - & 1.17 & 1.49 & - \\
\hline
\end{tabular}


history, this field being the only one available under manageable conditions. Only some indications on the nature of the influence of fertility can be derived from the results. As the treatments were an addition series, we use land equivalent ratio (LER) instead of RYT.

Average yields of field dry seeds of maize and groundnuts are presented in Table 6. The figures for the $F_{0}$ series are largely distorted by the high yield of especially maize in one replication, which apparently was much more fertile than the others. Relative figures like LER, when calculated for each replication, are less sensitive to this kind of distortion. Average LER figures are shown in Table 6 together with LERs calculated from average yields. The large discrepancy between the two for $\mathrm{F}_{0}$ is caused by the high fertility replication, as its contribution to the average yield is large. The high average LER values in the $F_{0}$ plots are explained by the low average number of cobs per plant in the pure maize stands (Table 7): in the unfertile replications the pure stand density of maize apparently was above optimum (cf. de Vos \& Sinke, 1973). In the mixtures a higher population pressure is tolerated, leading to a high LER. The LER values of the $F_{0}$ plots were therefore significantly higher than those of the $F_{1}$ plots $(P<0.05, F$ test $)$. This means, in other words, that mixtures of maize and groundnuts are better buffered against different fertility (probably N) levels than are pure maize stands, thus reducing the risk of yield decrease due to supra-optimal population density.

\section{Conclusions}

Mixtures of maize and groundnuts were found to be superior to pure stands in terms of RYT in Experiments 1 and 2. This means that a larger area of the pure crops would be needed in order to obtain the same yield of each species as in the mixtures.

It seems likely that the element responsible for the superiority of mixtures in these experiments was nitrogen. Each maize plant disposes of a larger soil volume for its $\mathbf{N}$ nutrition in mixtures than in pure stands, as groundnuts will satisfy their needs largely from their own $\mathbf{N}$ fixation. Under limiting $\mathrm{N}$ conditions a given population pressure of pure maize may be above optimum, whereas the same population pressure for mixtures is not: the mixtures are buffered against low fertility (probably N) levels. This effect is suggested by Experiment 3. Fisher (1977) found the opposite effect for mixtures of maize and beans under limiting water supply, where both crops would compete for the same limiting factor. He found equivalent areas (= LER) for seed yields of the mixtures to be substantially less than 1 . The population pressure for the mixtures, however, was higher than for the pure stands. The number of cobs per plant in the mixtures was much lower than in the pure stands. This strongly suggests that the population pressure in the mixtures was beyond the optimum for that season. If a correction had been made for this population pressure effect, values of near unity might have been obtained because both crops in the mixture competed for the same limiting factor.

It is desirable to include population density as a variable in experiments on mixed cropping (cf. Huxley \& Maingu, 1978). 


\section{MIXED CROPPING EXPERIMENTS WITH MAIZE AND GROUNDNUTS}

\section{Acknowledgments}

Thanks are due to Dr G. Bol Alima, director of ENSA, Nkolbisson, Cameroun, for permission to publish the results.

Discussions with Dr J. P. van den Bergh, which led to significant improvement of the text, are gratefully acknowledged.

\section{References}

Andrews, D. J., 1972. Intercropping with sorghum in Nigeria. Expl. Agric. 8: 139-150.

Beets, W. C., 1977. Multiple cropping of maize and soya beans under a high level of crop management. Neth. J. agric. Sci. 25: 95-102.

Fisher, N. M., 1977. Studies in mixed cropping. I. Seasonal differences in the relative productivity of crop mixtures and pure stands in the Kenya Highlands. Expl. Agric. 13: 177-184.

Fisher, N. M., 1977a. Studies in mixed cropping. II. Population pressures in maize-bean mixtures. Expl. Agric. 13: 185-191.

Fisher, N. M., D. Laycock, B. S. K. Masyanga \& J. O. Owuor, 1976. Report on mixed cropping experiments in the West of Kenya during the 1975 season. Tech. Comm. Dept. Crop Sci. Fac. Agric. Nairobi, Kenya No 16.

Huxley, P. A. \& Z. Maingu, 1978. Use of a systematic spacing design as an aid to the study of inter-cropping: Some general considerations. Expl. Agric. 14: 49-56.

IRRI, 1974. Cropping systems program and lessons from traditional technology. IRRI Annual Report for 1973, Los Baños, Philippines.

Norman, D. W., 1974. Rationalising mixed cropping under indigeneous conditions: the example of Northern Nigeria. J. Devel. Stud. 11 (1) 3-21.

Osiru, D. S. O. \& R. W. Willey, 1972. Studies on mixtures of dwarf sorghum and beans (Phaseolus vulgaris) with particular reference to plant population. J. agric. Sci., Camb. 79: 531-540.

Syarifuddin, A., S. Effendy, I. G. Ismail \& J. L. McIntosh, 1974. Performance of corn, peanut, mungbean and soybean in monoculture and intercrop combinations of corn and legumes in dry season 1973. Contr. Centr. Res. Inst. Agric., Bogor No 12.

Trenbath, B. R., 1976. Plant interactions in mixed crop communities. In: Multiple cropping. Spec. Publ. Am. Soc. Agron. No 27: 129-169.

Vos, N. M. de \& J. Sinke, 1973. Standdichtheid en opbrengst van korrelmaïs (Plant density and yield of grain maize). Bedrijfsontwikkeling 4: 257-260.

Willey, R. W. \& D. S. O. Osiru, 1972. Studies on mixtures of maize and beans (Phaseolus vulgaris) with particular reference to plant population. J. Agric. Sci., Camb. 79: 517-529.

Wit, C. T. de \& J. P. van den Bergh, 1965. Competition between herbage plants. Neth. J. agric. Sci. 13: 212-221. 